\title{
Assessment of Body Mass Index of In-School Adolescents in Calabar Municality Local Government Area of Cross River State, Nigeria
}

\author{
Eyo Emem Efeffiom ${ }^{1 *}$, Essien Violet Abel ${ }^{2}$, Asido Esther Edet ${ }^{1}$ and \\ Omeh Bassey Anthony ${ }^{1}$ \\ ${ }^{1}$ Department of Medical Laboratory Science, College of Health Technology, Calabar, Nigeria \\ ${ }^{2}$ Department of Public Health Science, Faculty of Allied Medical Sciences, University of \\ Calabar, Calabar, Nigeria \\ *Corresponding author
}

\begin{tabular}{|c|}
\hline Keywords \\
\hline $\begin{array}{l}\text { Adolescents, Body } \\
\text { mass index, Calabar } \\
\text { Municipality, } \\
\text { Prevalence of obesity, } \\
\text { Prevalence of } \\
\text { underweight, Obesity, } \\
\text { Overweight, } \\
\text { Underweight }\end{array}$ \\
\hline Article Info \\
\hline $\begin{array}{l}\text { Accepted: } \\
10 \text { December } 2017 \\
\text { Available Online: } \\
10 \text { January } 2018\end{array}$ \\
\hline
\end{tabular}

This research assessed the body mass index of in school adolescents in Calabar municipality Local Government Area of cross River State, Nigeria. A total of 454 adolescents (10-19 years) consisting of 218 males and 236 females were randomly selected from 7 study schools in the Local Government Area. A semi-structured questionnaire was used to collect data on background information of the adolescents concerning the topic. Anthropometric measurements (weight and height) of the adolescents were obtained, and used to calculate the Body Mass Index (BMI). Their BMI were categorized into obesity, overweight, normal and thinness using the International Obesity Task Force (IOTF) reference and the WHO BMI classification for adolescents up to 19 years. The data obtained were analyzed using Statistical Package for Social Sciences (SPSS), version 20. The prevalence of overweight, obesity and underweight among adolescents were $7.7 \%$, $1.1 \%$ and $32.8 \%$ respectively. The prevalence of obesity among the adolescents in private was $2.1 \%$ compared to the $0.0 \%$ in the public schools. On the other hand, public school had a high percentage of underweight adolescents; 106(65.4\%) while the private school had $56(34.5 \%)$ of the total underweight adolescents. There was a higher prevalence of overweight and obesity among females than among males, with the chi square showing a statistically significant value of $\mathrm{p}<0.05$. Unhealthy BMI is creeping into the population with underweight and overweight dwelling side by side though the prevalence of underweight $(32.8 \%)$ is higher, measures should be taken to tackle this issue from both ends as either way constitute a serious health challenge.

\section{Introduction}

The disparities in the body mass index of adolescents across the population overtime are a cause of concern as unhealthy body mass index has become a prevailing condition. The increase in the percentage of children and adolescents obese overtime is not just an indication of the morbidity and mortality increase among the population but also a health indicator for the measurement of the health of the entire population being that obesity have been shown to be highly associated with non-communicable 
disease(NCDs) such as type 2 diabetes, hypertension and ischemic heart disease both in longitudinal and cross sectional overweight and obesity in Nigerian population (HMR, 2014). Adolescents represent approximately $20 \%$ of the world's population and most $(\sim 84 \%)$ are living in developing or emerging countries (Melaku et al., 2015). The World Health Organisation describes obesity as a global epidemic and as such the need to assess the prevalence and to find the factors responsible so as to implement timely interventions (Bengalorkar et al., 2012). The consequences of underweight on the other hand are as grievous as that of overweight, for example, Amenorrhea (complete cessation of menses) occurs in 2 to $5 \%$ of women of reproductive age, and $40 \%$ of female athletic groups such as dancers, skaters, cheerleaders, gymnasts, cross-country runners and oligomenorrhea (irregular menstrual cycles) or amenorrhea increases the risk of bone loss and musculoskeletal injury in premenopausal women (NEDA, 2016). Obesity (a result of high body mass index) cuts across all ages and nations, it is said to be one of the leading cause of mortality and morbidity in both developed and developing countries (Adedayo et al., 2013). It is a major health problem and there is an increasing trend of underweight and obesity among individuals in countries around the world (Medline plus, 2015).

Under-nutrition has far reaching consequences, especially in girls. If their nutritional needs are not met, they have high risk of mortality as a result of pregnancy and childbirth and they are more likely to give birth to low birth weight infants. Furthermore, in all adolescents, short stature resulting from chronic under-nutrition is associated with reduced lean body mass and deficiencies in muscular strength and working capacity (Esimai and Ojofeitimi, 2015).

Adolescence obesity, which occurs most of the time due to untreated childhood obesity is said to be on the increase worldwide, in developing countries especially in the urban population as such emerging as a major health issue (IJO, 2012). Over years there has been substantial increase in childhood and adolescents overweight and obese in developed countries with $23.8 \%$ in boys and $22.6 \%$ in girls and in developing countries as well, from $8.1 \%$ to $12.9 \%$ in boys and from $8.4 \%$ to $13.4 \%$ in girls as at 2013 (Lancet, 2014). Another report in 2013, has it that 42 million people under the age of 5 were overweight or obese (considering its role in adolescence obesity), obesity which was said to be a high income problem is now on the increase in the low and middle income countries, particularly in the urban setting; out of these 42 million reported, 31 million are living in the developing countries (WHO, 2016). In developing countries, obesity has been reported to be $30 \%$ higher than that of developed countries (Medicentre, 2015).

In Nigeria, data on the prevalence of overweight and obesity among adolescents are few (Ojotetimi, 2011), as cited by Mustapha and Sanusi (2013) in their study of obesity among school children, however, a prevalence of $18 \%$ among school children has been reported in Nigeria (Sebanjo et al.,, 2011). Ben-Bassey et al., reported over all prevalence rates of overweight and obesity in urban and rural area as $3.7 \%$ and $0.4 \%$ respectively and $3.0 \%$ and $0.0 \%$ among children $10-19$ years in Eti-osa Local Government Area of Lagos state (Mustapha and Sanusi, 2013). In Cross River state, a prevalence rate of obesity and overweight of $1.7 \%$ and $6.8 \%$ respectively was reported by Ansa et al., in 2007 (Mustapha et al.,, 2013). Being that obese and overweight children and adults are likely to stay obese into adulthood and more likely to develop non communicable diseases like diabetes and cardiovascular diseases at a younger age, overweight and obesity as well as their diseases are preventable, and this 
prevention needs high priority as reported by the World Health Organisation journal on Global Strategy on diet, physical activity and Health (WHO, 2016).

According to Joseph Okoghenun's report on poverty and paradox of obesity in Nigeria, has it that the president of the Nutrition Society of Nigeria(NSN), professor NgoziNnam, a professor of public health nutrition blamed the trend of obesity among the poor on over reliance on carbohydrates such as yam, rice, garri (cassava produce), among others. She further explained lack of information on nutrition as one of the major contributing factors, she cautioned that something should be done about this: government should sponsor sensitization programmes on nutrition (Okoghenun, 2015). In his report, he added that will be years when obesity among the poor will be a double jeopardy for Nigeria to handle, as the poor do not have the financial wherewithal to seek medical care when they are faced with non-communicable diseases (NCDs) (Okoghenun, 2016).

An overview of the centre for disease control (CDC) facts on childhood obesity has it that; childhood obesity has more than doubled in children and quadrupled in adolescents in the past 30 years. The percentage of children aged 6-11years in united states who were obese increased from $7 \%$ in 1980 to nearly $18 \%$ in 2012, similarly, the percentage of adolescents aged 12-19 years who were obese increased from $5 \%$ to nearly $21 \%$ over the same period, in 2012, more than one third of children and adolescents were overweight or obese (Ogden, Carroll and Elegal, 2014).

It is in view of these context of rise in prevalence of obesity and overweight in the urban settings of developing countries that this study is conducted to assess the prevalence among adolescents in Calabar municipality: an urban setting in cross river, Nigeria (a developing country) to determine their knowledge on the relationship between high body mass index and non-communicable diseases, also to compare the findings with other studies conducted on the topic; especially with that of Ansa et al., in Cross River State.

\section{Materials and Methods}

\section{Study area}

This study was conducted from January to September, 2016 in Calabar Municipality Local Government Area of Cross River State, Nigeria. It is an urban setting, the capital city of Cross River State. It was the capital of Southern Protectorate of Nigeria and lost that to Lagos in 1904. It is one of the earliest sits of local government administration in the Eastern Region up to 1952 under the ordinance of 1950 (CRSMI, 2006). It lies between latitude $04^{0} 15^{\prime}$ and $5^{0} 15 \mathrm{~N}$ and longitude $8^{0} 15^{\prime}$ and $8^{0} 25^{\prime} \mathrm{E}$. It has an area of $331.551 \mathrm{~km}^{2}$ with a population of 179,392 at the 2006 census. The postal code of the area is 540. The Municipality is bounded in the North by Odukpani Local Government Area in the North-East by the great Kwa River, it Southern Shores are bounded by Calabar River and Calabar South Local Government Area (NIPOST, 2012). It plays a dual role; the capital city of Cross River State and the headquarters of Southern Senatorial District.

The ethnic groups form the indigenous population; these are the Quas and the Efiks. However, due to its cosmopolitan status there abound people from all parts of the state and Nigeria in the city. By virtue of its location along the water front, the Efiks embraced Western culture early through their trade with the Europeans. Fishing was another occupation identified with them, while the Quas on the other hand occupy the bulk of the hunter land of Calabar where farmers, traders 
and blacksmiths were found, moreover due to the tremendous transformation undergone by the area with improved social amenities, recreational facilities, industries, and others, occupation of the resident had tilted from fishing and farming to civil service, public service company workers amongst other occupations. It is made up of 10 wards and numerous villages with the current Chairman; Mr. Etim Donatus Henry who is running the administration affairs of the area (CRGIA, 2014).

\section{Subjects selection}

A total number of four hundred and fifty four (454) in school adolescents (aged 10 - 19) was selected from five wards out of the 10 wards in the study area using systematic sampling technique.

\section{Ethical consideration}

A letter of introduction and ethical clearance was received from the department of Public Health; University of Calabar, copies were made and send to the principals of the selected schools. The rudiments of the research were explained to volunteered participants with their verbal consent and a signed letter of consent from their parents before data collection. The participants were assured of confidentiality of information. Benefits of the research were shared and equity sustained throughout the research period.

Instruments and materials for data collection

\section{The questionnaire}

A semi structured questionnaire (made up of closed and open ended questions) was used to collect data on the knowledge and perception of the participants about the subject of interest.

\section{Materials for data collection}

To take the anthropometric measurement, the following materials were used:

Weighing scale; to measure the weight of participants

Height scale; to take height measurements of participants

The body mass indexes of participants were assessed to help identify underweight and obese individuals.

\section{Methods for data analysis}

Data collected from the field were analysed using the Statistical Package for Social Sciences (SPSS) software application version 20 for proper analysis. The analysis was both descriptive and analytical as data will be presented in percentages on frequency tables and figures where applicable to analyse the view of participants on questions of interest.

\section{Results and Discussion}

Result of the study shows that of the 454 respondents, 218 (48\%) were males while 236 $(52 \%)$ were females. The mean age of the respondents was 14.3years (Table 1). Out of the 454 participants, $229(51.2 \%)$ were from Private Schools and 225(48.8\%) were from Public/Government Schools. Out of the 454 participants, 100 (22.0\%) were from J S 1, $118(26 \%)$, from J S 2, 123(27.1\%) were from S S 1 while 113(24.9\%) were from S S 2, distribution by age when grouped into interval showed that the 13-15 interval had the highest participants with $265(58.5 \%)$, 16-18 had $105(22.4 \%), 10-12$ had $79(17.4 \%)$ while 19 had $8(1.8 \%)$ participants. Table 1 shows the section A part of the questionnaire which covers the demographic information of the respondents. 
On the question of knowing what BMI is, 160(35.2\%) answered yes while 293(64.5\%) answered no to this question.

On the scored questions, a rank was made according to the scores of the participants; no knowledge level (0) 45 (9.9\%) of the students reported that they have no knowledge of BMI, $240(52.9 \%)$ indicated low knowledge level (1$3), 148(32.6 \%)$ of the participants indicated moderate level of knowledge (4-6) and $21(4.6 \%)$ of students shows high knowledge level (7-10) see (pie-chart 1).

The responses to the answers given on questions about knowledge are shown in table 2. From the table, it is seen that out of the 454 participants only $160(35.24 \%)$ had previous idea on what BMI is. On the factors that affects BMI, $219(48.2 \%)$ of the 454 respondents agreed that poor nutrition can affect the BMI of an adolescent, 148(32.5\%) said the socioeconomic status of the parents is a major factor, 193(42.5\%) said that the environment also plays a role, $133(29.2 \%)$ said that gender is a major factor, 135(29.7\%) reported that fast food meals is a major factor, $196(43.17 \%)$ said that illness is a major factor while 213(46.9\%) reported that family background is the outstanding factor.

\section{Risk factors and effect of unhealthy BMI}

Selected questions on risk factors and complications of BMI either underweight or obesity were asked and the participants gave their view on the questions. Out of the 454 participants, 222(48.9\%) (the highest response for the question) said that sickness can cause underweight while 169(37.2\%) (lowest response) reported that puberty is a major risk factor, on high BMI, 179(39.4\%) identified gender as a factor while 192(42.3\%) said that food is a major factor. On the effects of low BMI, 188(41.4\%) agreed that underweight will lead to stunted growth while 171(37.7\%) reported that delayed puberty is a major effect of underweight, for high BMI, 208(45.8\%) indicated that aggressiveness is a major effect while 170(37.8\%) said that learning problems is the most prevalent effect of obesity (Table 3).

Table 3 shows the frequencies and percentages for the positive responses given to the questions out of the total number of responses.

\section{Prevention of unhealthy BMI}

Section D covered suggested points for prevention and control of unhealthy BMI among adolescents. Questions were asked on this and the answers given were analysed and the analysis showed that respondents recommended increase sleep hours as a means of controlling underweight than any other means (204 respondents out of 454) while for high BMI, 265(58.4\%) recommended that more exercise will prevent obesity. Table 4 shows responses with the highest recommendation on selected categories (Table 4). An open ended question was asked on the safest way of preventing the prevalence of obesity and the responses given on this is shown on a histogram (histogram 1).

\section{BMI by gender of participants}

Showing BMI by gender, out of the 236 females assessed, 28 were overweight while 61 were underweight and 5 obese while 142 had healthy body mass index. For the 218 males assessed, 7 were overweight and 101 were underweight none was obese, whereas 110 maintained a healthy body mass index (Table 2).

\section{BMI by socioeconomic status of parents}

To analyse this variable, figures were assigned in ranks to the three socioeconomic classes; low, moderate and high socioeconomic status of parents. 
Table.1 Demographic characteristics of respondents

\begin{tabular}{|l|l|l|l|l|}
\hline $\mathbf{s} \mathbf{n}$ & Variables & Group & Frequency $\mathbf{n = 4 5 4}$ & Percentage (\%) \\
\hline $\mathbf{1}$ & Gender & Male & 218 & 48.0 \\
& & Female & 236 & 52.0 \\
& School & Private & 229 & 51.2 \\
& & Public & 225 & 48.8 \\
\hline $\mathbf{3}$ & Class & J S 1 & 100 & 22.0 \\
& & J S 2 & 118 & 26.0 \\
& & S S 1 & 123 & 27.1 \\
4 & S S 2 & 113 & 24.9 \\
& Age(years) & $10-12$ & 79 & 17.4 \\
& & $13-15$ & 265 & 58.5 \\
& & $16-18$ & 102 & 22.4 \\
& 19 & 8 & 1.8 \\
\hline
\end{tabular}

Average age $=14.5$ mean for age $=5.32$, mode $=6.00$ and median $=6.0$

Source: Result from field

Table.2 Knowledge of BMI

\begin{tabular}{|c|c|c|c|c|}
\hline Variable & Category & $\begin{array}{l}\text { Female } \\
\mathrm{F}(\%)\end{array}$ & $\begin{array}{l}\text { Male } \\
\text { F(\%) }\end{array}$ & $\begin{array}{l}\text { Total } \\
\text { F(\%) }\end{array}$ \\
\hline \multirow{3}{*}{$\begin{array}{l}\text { Do you know what } \\
\text { BMI is? }\end{array}$} & Yes & $83(51.8)$ & $78(45.75)$ & $160(100)$ \\
\hline & No & $153(52.2)$ & $140(47.7)$ & $293(100)$ \\
\hline & Total & 236(51.9) & $218(48.0)$ & $454(100)$ \\
\hline \multirow{3}{*}{$\begin{array}{l}\text { The ratio of weight } \\
\text { to height }\end{array}$} & Yes & $67(28.3)$ & $59(25.0)$ & $126(100)$ \\
\hline & No & $169(77.5)$ & $159(72.9)$ & $218(100)$ \\
\hline & Total & $126(27.7)$ & $328(72.2)$ & $454(100)$ \\
\hline \multirow[t]{3}{*}{$\begin{array}{l}\text { Fat content of the } \\
\text { body }\end{array}$} & Yes & $45(50.5)$ & $44(49.4)$ & $89(100)$ \\
\hline & No & 191(52.47) & $174(47.8)$ & $364(100)$ \\
\hline & Total & 236(51.9) & $218(48.0)$ & $454(100)$ \\
\hline \multirow[t]{2}{*}{$\begin{array}{l}\text { Test to determine } \\
\text { the weight of the } \\
\text { body }\end{array}$} & Yes & $48(43.2)$ & $68(61.2)$ & $111(100)$ \\
\hline & $\begin{array}{l}\text { No } \\
\text { Total }\end{array}$ & $\begin{array}{l}188(54.8) \\
\mathbf{2 3 6}(51.9)\end{array}$ & $\begin{array}{l}155(45.1) \\
\mathbf{2 1 8}(\mathbf{4 8 . 0})\end{array}$ & $\begin{array}{l}343(100) \\
\mathbf{4 5 4}(\mathbf{1 0 0})\end{array}$ \\
\hline \multirow[t]{3}{*}{ Ever tested? } & Yes & $105(51.9)$ & $97(48.0)$ & $202(100)$ \\
\hline & No & $131(52.1)$ & $121(48.2)$ & 251(100) \\
\hline & Total & $236(51.9)$ & $218(48.2)$ & $454(100)$ \\
\hline
\end{tabular}


Table.3 Risk factors and effects of unhealthy BMI

\begin{tabular}{|c|c|c|c|}
\hline Variable & Category & $\begin{array}{l}\text { Positive } \\
\text { Response F(\%) }\end{array}$ & $\begin{array}{l}\text { Total } \\
\text { F(\%) }\end{array}$ \\
\hline $\begin{array}{l}\text { What do you think } \\
\text { can cause } \\
\text { underweight? }\end{array}$ & $\begin{array}{l}\text { Obsessive exercise } \\
\text { Puberty } \\
\text { Sickness } \\
\text { Excess carbohydrate }\end{array}$ & $\begin{array}{l}189(41.0) \\
169(37.2) \\
222(48.9) \\
184(40.5)\end{array}$ & $\begin{array}{l}454(100) \\
454(100) \\
454(100) \\
454(100)\end{array}$ \\
\hline $\begin{array}{l}\text { What are the risk } \\
\text { factors for obesity? }\end{array}$ & $\begin{array}{l}\text { Gender } \\
\text { Ethnicity } \\
\text { Wealthy family } \\
\text { Excess food }\end{array}$ & $\begin{array}{l}179(9.4) \\
130(28.6) \\
139(30.6) \\
192(42.3)\end{array}$ & $\begin{array}{l}454(100) \\
454(100) \\
454(100) \\
454(100)\end{array}$ \\
\hline $\begin{array}{l}\text { What are the effects } \\
\text { of underweight? }\end{array}$ & $\begin{array}{l}\text { Stunted growth } \\
\text { Compromised immune } \\
\text { system } \\
\text { Delayed puberty }\end{array}$ & $\begin{array}{l}188(41.4) \\
179(39.4) \\
171(37.7)\end{array}$ & $\begin{array}{l}454(100) \\
454(100) \\
454(100)\end{array}$ \\
\hline $\begin{array}{l}\text { What are the effects } \\
\text { of obesity? }\end{array}$ & $\begin{array}{l}\text { Learning problems } \\
\text { Aggressiveness } \\
\text { Depression } \\
\text { Hypertension }\end{array}$ & $\begin{array}{l}170(37.8) \\
188(41.4) \\
208(45.8) \\
176(38.8)\end{array}$ & $\begin{array}{l}454(100) \\
454(100) \\
454(100) \\
454(100)\end{array}$ \\
\hline
\end{tabular}

Table.4 Section D: prevention of unhealthy BMI

\begin{tabular}{|c|c|c|c|}
\hline Variable & Category & $\begin{array}{l}\text { Positive Response } \\
\text { F(\%) }\end{array}$ & Total F(\%) \\
\hline $\begin{array}{l}\text { How would you } \\
\text { prevent } \\
\text { underweight? }\end{array}$ & $\begin{array}{l}\text { Increase sleep hours } \\
\text { Increase calorie } \\
\text { Reduce exercise }\end{array}$ & $\begin{array}{l}204(44.9) \\
186(41.0) \\
153(33.8)\end{array}$ & $\begin{array}{l}454(100) \\
454(100) \\
454(100)\end{array}$ \\
\hline $\begin{array}{l}\text { How would you } \\
\text { prevent obesity? }\end{array}$ & $\begin{array}{l}\text { More exercise } \\
\text { Reduce food intake } \\
\text { Abstinence from fast } \\
\text { food meals }\end{array}$ & $\begin{array}{l}265(58.4) \\
246(54.2) \\
251(56.3)\end{array}$ & $\begin{array}{l}454(100) \\
454(100) \\
454(100)\end{array}$ \\
\hline
\end{tabular}


Table.5 BMI by gender, school type, age and socioeconomic status

\begin{tabular}{|c|c|c|c|c|c|c|c|}
\hline Variables & Category & $\begin{array}{l}\text { Underweight } \\
\text { F(\%) }\end{array}$ & $\begin{array}{l}\text { Healthy } \\
\mathrm{F}(\%)\end{array}$ & $\begin{array}{l}\text { Overweight } \\
\text { F(\%) }\end{array}$ & $\begin{array}{l}\text { Obese } \\
\text { F(\%) }\end{array}$ & $\begin{array}{l}\text { Total } \\
\text { F }(\%)\end{array}$ & P-value \\
\hline \multirow[t]{3}{*}{ Gender } & Male & $101(46.3)$ & $110(50.5)$ & $7(3.1)$ & $0(0.0)$ & $218(100)$ & \\
\hline & Female & $61(25.8)$ & $142(60.1)$ & $28(11.8)$ & $5(2.1)$ & $236(100)$ & 0.000 \\
\hline & total & $162(35.7)$ & $252(55.5)$ & $35(7.7)$ & $5(1.1)$ & 454(100) & \\
\hline \multirow[t]{3}{*}{ School } & Private & $56(24.2)$ & $148(64)$ & $22(9.5)$ & $5(2.1)$ & 231(100) & \\
\hline & Public & $106(47.5)$ & $104(46.6)$ & $13(5.8)$ & $0(0.0)$ & 223(100) & 0.000 \\
\hline & Total & $162(35.7)$ & $252(55.5)$ & $35(7.7)$ & $5(1.1)$ & 454(100) & \\
\hline \multirow{4}{*}{$\begin{array}{l}\text { Socioeconomic } \\
\text { Status of } \\
\text { parents }\end{array}$} & Low & $92(82.8)$ & $19(17.1)$ & $9(8.1)$ & $0(0.0)$ & 111(100) & \\
\hline & Average & $56(22.6)$ & $162(65.5)$ & $26(10.5)$ & $1(0.4)$ & $247(100)$ & \\
\hline & High & $14(14.5)$ & $71(73.1)$ & $9(9.3)$ & $4(4.1)$ & $96(100)$ & 0.000 \\
\hline & Total & $162(35.5)$ & $252(55.5)$ & $35(7.7)$ & $5(1.1)$ & 454(100) & \\
\hline Age & $\begin{array}{l}10-12 \\
13-15 \\
16-18 \\
19 \\
\text { Total }\end{array}$ & $\begin{array}{l}27(36.9) \\
140(52.8) \\
45(44.1) \\
5(62.5) \\
\mathbf{1 6 2 ( 3 5 . 5 )}\end{array}$ & $\begin{array}{l}48(60.7) \\
154(58.1) \\
48(47.0) \\
2(25) \\
\mathbf{2 5 2 ( 5 5 . 5 )}\end{array}$ & $\begin{array}{l}4(5.0) \\
21(7.9) \\
10(9.8) \\
0(0.0) \\
\mathbf{3 5}(7.7)\end{array}$ & $\begin{array}{l}0(0.0) \\
3(1.1) \\
1(0.9) \\
1(12.5) \\
\mathbf{5 ( 1 . 1 )}\end{array}$ & $\begin{array}{l}79(100) \\
265(100) \\
102(100) \\
8(100) \\
\mathbf{4 5 4 ( 1 0 0 )}\end{array}$ & \\
\hline
\end{tabular}

Fig.1 Pie chart 1 showing the knowledge level of participants

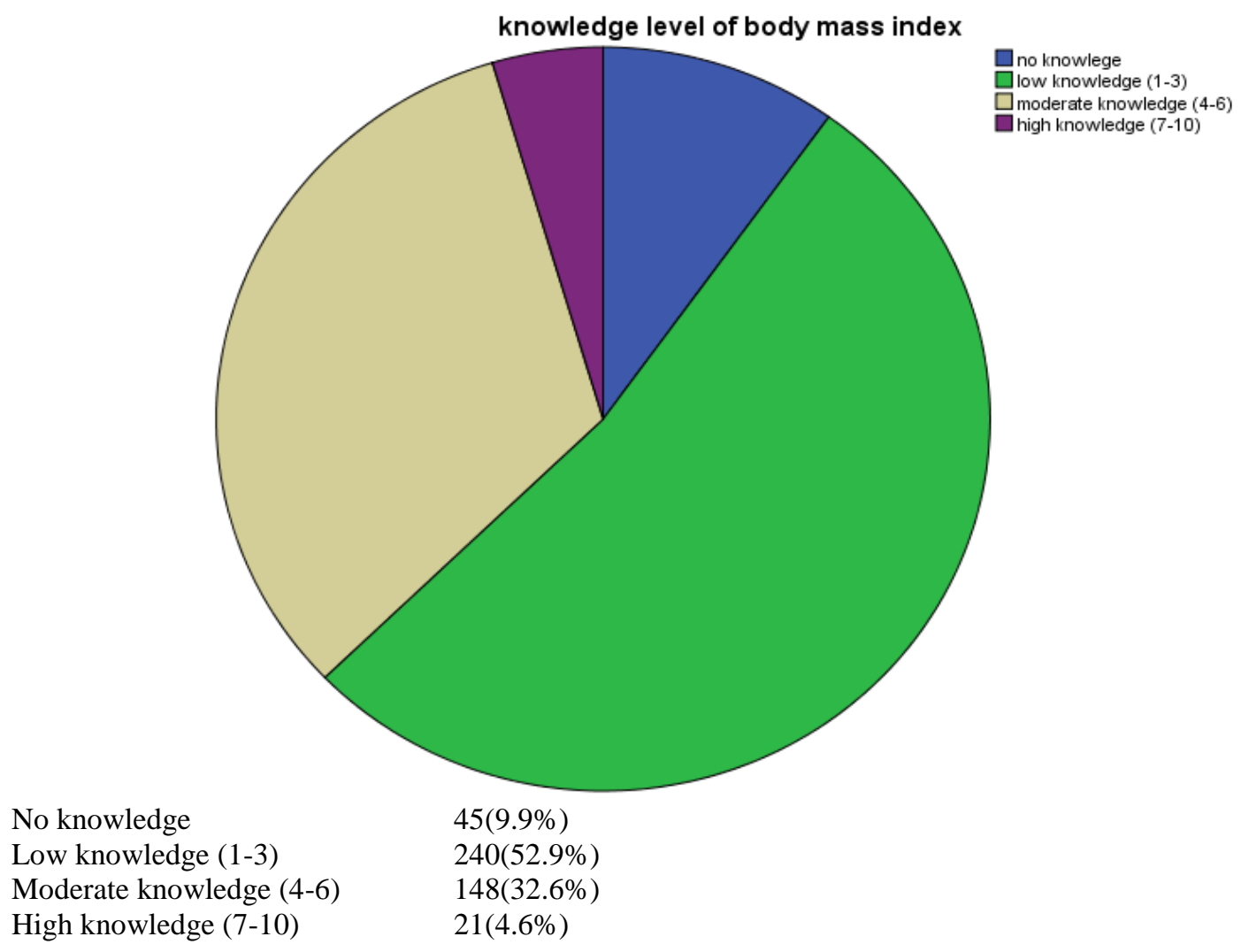




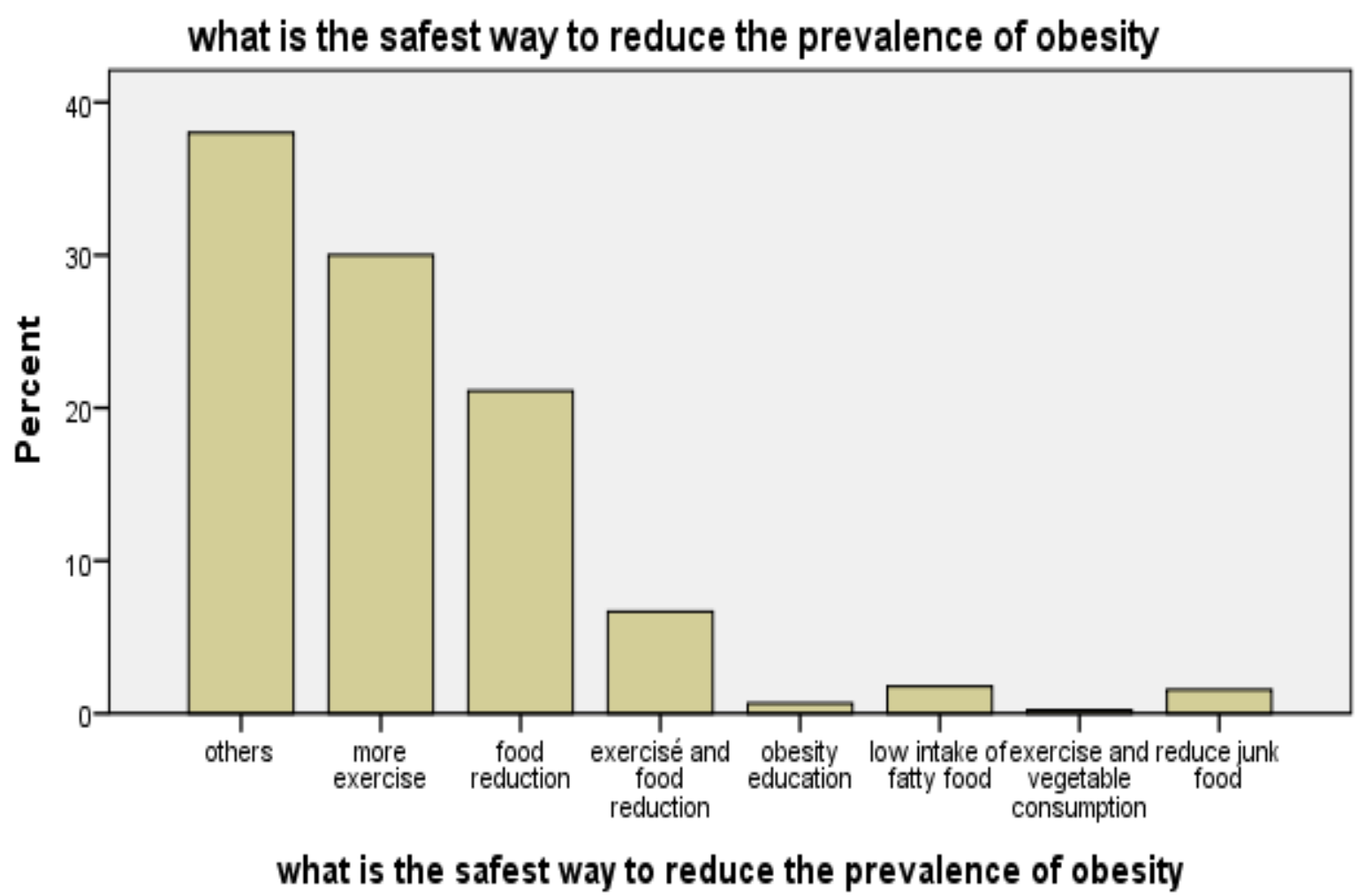

When analysed, the result showed that participants with low socioeconomic parents were a total of 111 and out of this, 92 were underweight while 19 where healthy, for moderate socioeconomic status, out of 247 participants, 56 were underweight, 162 were healthy, 26were overweight while 1 was obese. Whereas for high socioeconomic status, out of 96 participants, 14 were underweight, 71 were healthy, 9 were overweight and 4 were obese.

\section{BMI by schools of participants}

The research also compares the BMI of participants in private schools to those in public schools. Of the 454 participants, $229(51.2 \%)$ were from private owned school while 225(48.8\%) were from public/government owned schools. Of this, the public schools in total had 106 underweight students, 104 healthy students, 13 overweight students and no obese student while the private owned school had a total of 56 underweight students, 148 healthy students, 22 overweight and 5 obese students.

\section{Relationship between sex and obesity}

Null hypothesis (Ho): There is no significant relationship between sex and high body mass index

Alternate hypothesis (Ha): There is a significant relationship between sex and high body mass index

For this variable, out of the 236 females assessed, 28 were overweight while 60 were underweight and 5 obese while 143 had healthy body mass index. For the 168 males assessed, 7 were overweight and 89 were underweight none was obese, whereas 122 maintained a healthy body mass index. From the chi square test, $(\mathrm{p}=0.00)$, i.e. $\mathrm{p}<0.05$, therefore we reject the null hypothesis and 
accept the alternate hypothesis which states that; There is a significant relationship between sex and high body mass index.

The study shows the body mass index of participants with a prevalence of underweight of $32.8 \%$, overweight of $5 \%$ and $1 \%$ obesity among in-school adolescents in Calabar municipality Local Government Area of Cross River State, Nigeria. In Cross River state, a prevalence rate of obesity and overweight of $1.7 \%$ and $6.8 \%$ respectively was reported by Ansa et al., in 2007 (Mustapha et al.,, 2013), in comparing this with the results, it shows that there has been a decrease in the prevalence of overweight and obesity from $1.7 \%$ and $6.8 \%$ respectively in 2007 to $5 \%$ and $1 \%$ respectively in 2016 . The result shows a higher prevalence of underweight of $32.8 \%$ compared to $1 \%$ of obese adolescents among the population.

The study also assessed the prevalence of underweight among the population and it was discovered that the prevalence of underweight [162(35.7\%)] was more than that of overweight $[35(7.7 \%)]$ and obesity $[5(1.1 \%))$. This result of high prevalence of underweight among adolescents agrees with Esimai and Ojofeitimi's work where they mentioned that one of the major global health problems faced by developing countries today is under nutrition which is a factor for underweight (Esimai and Ojofeitimi, 2015).

The issue of gender and high body mass index assessed in this study is in line with an article in the World Health Organisation's journal on body mass index of adolescents where it was stated that the drastic increase in the prevalence of overweight and obesity calls for an assessment and rapid action to reduce the rates. In developed countries, an increase of $23.8 \%$ for boys and $22.6 \%$ for girls and in developing countries, $8.1 \%$ to $2.9 \%$ increase in boys and from $8.4 \%$ to13.4 in girls has been reported (WHO, 2014), showing that girls always have higher BMI than boys.

In conclusion, Body mass index is the simple index that indicates the ratio of weight to height of an individual in kilograms per metres square. It is an objective method for measuring the anthropometric features of an individual. This method is effective for both adolescents and adults. The issue of unhealthy BMI cuts across various populations and is more prevalent in developing countries where obesity and underweight dwells side by side. The research has been able to expose the various risk factors of this problem and identify the major issue with it. The necessity to start sensitization on unhealthy BMI cannot be underestimated as the health status of adolescents serves as a health indicator for the entire population reasons being that they are the future adults of any population

\section{Acknowledgement}

We thank God Almighty for his grace throughout the course of this research. We thank our research assistants for helping in data collection. Our gratitude also goes to Dr. Bernadine Ekpenyong for her support and the principals of the selected schools for their cooperations.

\section{References}

Adedayo, O. Sagbageh, Ebenezar, and Ojotutimi, O. 2013. a study on the Prevalence of Obesity among Adolescents in Ile-Ide, Osun State, Nigeria. Nigeria.

Ahmad, M., Ahmed, H., and Airedek. 2013. BMI among School adolscents in Sokoto, north-estern Nigeria. Sahel Medicine Journal, 5-9.

Bengalorkar, B., P.K, G.M, R, D, C, et al., 2012. Prevalence of overweight and obesity among adolescents of school 
going age(12-15)years in Urban Area, south India. International Journal of Current Research and Review, 99-105.

Bengalorkar, B., P.K, G.M, R, D, C, et al., 2012. Prevalence of overweight and obesity among adolescents of school going age (12-15) years in Urban Area, south India. International Journal of Current Research and Review, 99-105.

CDC. 2016. Growth Reference for children and adolescents. Centre for Disease Control and Prevention.

Churchill, L., 1999. pocket Medical Dictionary 14th Edition. Royal Society of medicine.

Coin, A., Sergi, G., P.Beninca, L,.., and Cinti, G. (2014, october 9). Home Remedy for Underweight. Retrieved may 23, 2016, from Home Remedies website: http;//www.home-remedies-foryou.com/remedy/underweight.html

Cynthia L. Ogden, P., Margaret D. Carroll, M., and Brian K. Kit, M. M. 2012. Prevalence of Obesity among adolescents in the United Staes. National Centre for Health Statistics Data Brief.

EASO. 2014. Obesity: Policy Makers survey 2014. European Association for the Study of Obesity.

Esimai, O., and Ojofeitimi, E. 2015. Nutrition and Health Status of Adolescents in a Private Secondary School in Port Harcourt. iMedPub Journals.

Gidus, T. (2014, september 4). Healthline. Retrieved May 24, 2016, from Healthline Website: http://www.health line.com/health-blogs/dietdiva/dangers-underweight.com

Heerden, I. V. (2013, August 5). Health 24. Retrieved May 23, 2016, from Health 24 website: http://www.health24.com

Henrietta Ene-Obong, V. I. 2012. Prevalence of overweight, obesity, and thinness. Food and Nutrition Bulletin, vol. 33, no.
4 (c) 2012, The United Nations University.

HMR. 2014. Prevalence of Overweight and Obesity among Urban Nigerian adults in Jos. Highland Medical Research Journal,

http://www.ajoc.info/index.php/hmr/arti cle/view/33792.

Hoffman, Ahl, Meyers, schuh, shult, and Jensen. 2012. Wellness Intervention for Patients with Serious and Persistent Mental Illness.

Hudgends, M. G. 2006. Study Designs in Public Health.

IJO. 2012. Prevalence of Obesity. Italian Journal of Public Health, 3-9.

Kenter, R., and Cabalero, B. 2015. Global Gender Disparities in Obesity; A Review. Open Acess Journal.

Krause. 2000. Krause's Food; Nutrition and Diet therapy 10th edition. USA: WB Suaders.

Macias, Rosas-Vargas, Keuver, and PerzCarciac. 2014. Perception of Obesity and Quality of Life. Mexico.

McLaughlin, A. (2012, March 23). Underweight. Retrieved May 24, 2016, from Live Strong: http://www. livestrong.com

Melaku, Y. A., Zelo, G. A., Gill, T. K., and Shi, R. J. 2015. Prevalence and factors associated with stunting and thinness among adolescent students in Northern Ethiopia: a comparison to World Health Organization standards. Arch Public Health, 44.

Mustapha, R. A., and Sanusi, R. A. 2013. Overweight and Obesity among Inschool Adolescents in Ondo State, Southwest Nigeria. African Journal of Biomedical Research.

NCBI. 2012. The Surgeon General's vision for a Healthy anf Fit Nation. National Centre for Biotrechnology Information.

NCBI. 2015. Global, regional and National prevalence of obesity in children and 
adults. National Center for Biotechnology Information, http://aaa.ncbi.nlm.nih.gov/PMC/article s/PMc4624264.

NCBI. 2016. Prevalence of overweight and obesity in adult Nigerians-a systematic review. National Center for Biotechnology Information, http://www.ncbi.n/m.nih.gov/PMC/artic les/PMC355.

NCHS. 2012. Obesity Complications. National Centre for Health statistics Journal.

NEDA. 2016. Losing the 3Ds: Dieting, Drive for Thinness and Body Dissatisfaction. Retrieved September 12, 2016, from National Eating Disorder Association: https://www.nationaleatingdisorders.org /losing-3ds-dieting-drive-thinness-andbody-dissatisfaction

NHLBI. 2016.

NIPOST. 2012. post offices with map of LGA. Retrieved may 8, 2016, from http://www.google-calabarmunicipailty-html

Okoghenun, J. (2016, march 23). Poverty and Pradox of Obesity in Nigeria. The Guardian Nigeria Newspaper.

Public Health Service, U. 2016. Psychiatric Medications and Obesity. America.
S.M, Y., M.S, M., I.D, G., and A.E, U. 2013. Overweight and Obesity among Adolescets in Nigeria. Nigeria.

Shehu, Muhammad, Baba, Ibrahim, and Andre. 2013. prevalence of obesity in Nigeria. Open Acess journal.

WHO. 2000. median growth reference for children and adolescents. World Health Organization Journal.

WHO. 2014. 10 Facts on Obesity. World Health Organization Journal, http://www.int/featuresfactfiles/obesity/ en/WHO/10factsonobesity.

WHO. 2015. Obesity and Overweight fact sheet. World health Organization.

WHO. 2016. Facts on underweight. World Health Organization Journal.

WHO. 2016. Knowledge and Perception of childhood Obesity among Parents. Paediatric Journal of public health.

Willson, S. 2016. wellness. National Centre for Biotechnology Information, retrived from http://health.howstuffworks. com/wellness/diet-fitness/weightloss/bmi4.htm.

Yusuf, S., Mijinyawa, I., Gezawa, M., and Uloko, A. 2013. Overweight and Obesity among Adolescets in Nigeria. Nigeria.

\section{How to cite this article:}

Eyo Emem Efeffiom, Essien Violet Abel, Asido Esther Edet and Omeh Bassey Anthony. 2018. Assessment of Body Mass Index of In-School Adolescents in Calabar Municality Local Government Area of Cross River State, Nigeria. Int.J.Curr.Microbiol.App.Sci. 7(01): 949-960. doi: https://doi.org/10.20546/ijcmas.2018.701.114 